|| ISSN(online): 2589-8698 || ISSN(print): 2589-868X || International Journal of Medical and Biomedical Studies

Available Online at www.ijmbs.info

PubMed (National Library of Medicine ID: 101738825)

Index Copernicus Value 2018: 75.71

Volume 3, Issue 4; April: 2019; Page No. 150-154

\title{
TO STUDY THE SEX SPECIFIC DISTRIBUTION OF VARIOUS DERMATOSES IN THE GERIATRIC POPULATION
}

\author{
Pankaj Rao ${ }^{1}$, Vineet Kumar ${ }^{2}$, Chandraprakash Chouhan ${ }^{3}$, Rekha $\mathrm{S}^{4}$ \\ 1,3 Department of Dermatology, Venereology and Leprosy, Dr. S.N. Medical College and A.G. of \\ Hospitals Jodhpur, Rajasthan \\ ${ }^{2,4}$ Department of Dermatology, Venereology and Leprosy, S.P. Medical College and A.G. of Hospitals \\ Bikaner, Rajasthan
}

Article Info: Received 21 March 2019; Accepted 18 April. 2019

Cite this article as: Rao, P., Kumar, V., Chouhan, C., \& S, R. (2019). TO STUDY THE SEX SPECIFIC DISTRIBUTION OF VARIOUS DERMATOSES IN THE GERIATRIC POPULATION. International Journal of Medical and Biomedical Studies, 3(4).

DOI: https://doi.org/10.32553/ijmbs.v3i4.205

Address for Correspondence: Pankaj Rao, Department of Dermatology, Venereology and Leprosy, Dr. S.N. Medical College and A.G. of Hospitals Jodhpur, Rajasthan

Conflict of interest: No conflict of interest.

\section{Abstract}

Background: In aging, a decline in the regular functions of skin is observed, including cell replacement capacity, barrier function, chemical clearance capacity, sensory perception, mechanical protection, wound healing, immune responsiveness, thermoregulation, sweat production, sebum production, vitamin D production, and capacity to repair DNA. As a result, some inevitable changes, such as roughness, wrinkling, and laxity of the skin, and atypical presentations of dermatologic diseases are observed in elderly patients.

Methods: Five hundred consecutive patients more than 60 years of age attending the outpatient clinic or admitted as inpatients in the Department of Dermatology, STD and Leprosy at MDM Hospital, Jodhpur were studied.

Results: Of the total of 500 participants in our study, 263 (52.6\%) were males and the rest were females. Most common dermatosis noted in the target population was benign tumors, present in 322 patients (64.4\%). Second most common disease group affecting the elderly was the infections and infestations group, being present in 215 patients (43\%). Infections were present in 195 patients (39\%) while infestations were present in 24 patients (4.8\%). Four patients presented with infection along with infestation.

Conclusion: Males outnumbered females with male to female ratio 1.11:1. The distribution and frequency of various dermatoses varies significantly from country to country and region to region

Keywords: Gender, Ageing, Dermatoses, Pruritus, Senile.

\section{Introduction}

October 1 is celebrated as International Elder's Day.

In the most countries of the world, the proportion of people of over 60 years old is growing faster than any other age group: this fact is happening as a result of both longer life expectancy and also of what we can determine as the declining fertility rates. This population ageing can be seen as a success story for public health policies and for socioeconomic 
development; on the other hand, it also challenges society to adapt, in order to maximize the health and functional capacity of older people ${ }^{1,2}$

United Nations considers 60 years as the age of transition to the elderly age group. In India, people aged 60 years and above are treated as old $^{3,4}$. In India the proportion of aged population was $5 \%$ in $1971,6 \%$ in $1981,6.7 \%$ in $1991,7.7 \%$ in 2001 and $8 \%$ in 2011 and is likely to rise to $19 \%$ by $2050{ }^{5}$. In figures, geriatric population was 96 million (2011) in India and it is estimated to rise to 150 million $(2025)^{6}$ and 324 million $(2050)^{7}$. This changing scenario has given rise to three major needs: social, health \& financial security to elderly.

In aging, a decline in the regular functions of skin is observed, including cell replacement capacity, barrier function, chemical clearance capacity, sensory perception, mechanical protection, wound healing, immune responsiveness, thermoregulation, sweat production, sebum production, vitamin $\mathrm{D}$ production, and capacity to repair DNA. As a result, some inevitable changes, such as roughness, wrinkling, and laxity of the skin, and atypical presentations of dermatologic diseases are observed in elderly patients ${ }^{8}$.

Geriatric health care has absorbed a worldwide attention, but few statistical studies were carried out about skin diseases in this age group. 30 years ago, the American HANES survey demonstrated that the frequency of skin disorders increases with age so that at the age of 70 some $70 \%$ had a significant skin condition and many others had multiple skin problems ${ }^{9}$

In this study, we attempted to determine the frequency as well as gender distributions of dermatological diseases in geriatric patients who attended dermatologic center of an educational hospital in Rajasthan, India.

\section{MATERIAL AND METHODS}

Study design: A hospital based cross-sectional study.
Study Place: Department of Dermatology, STD and Leprosy at MDM Hospital, Jodhpur

Study population: Five hundred consecutive patients more than 60 years of age attending the outpatient clinic or admitted as inpatients in the Department of Dermatology, STD and Leprosy at MDM Hospital, Jodhpur were studied.

Inclusion criteria

$>$ Patients attending the dermatology OPD at our hospital, aged 60 years or above.

Exclusion criteria

$>$ Patients $<60$ years age

$>$ Patients whose diagnoses could not be ascertained due to the patients' refusal to get the necessary investigations done.

Method of data collection

A written consent was taken from all the patients. Relevant history of the cutaneous complaints, present and past medical ailments, along with the patient's occupation, educational and income status were recorded. The patients were examined thoroughly in day-light and dermatological, general physical and systemic examination were carried out irrespective of the complaints. Detailed dermatological examination was done and all findings were noted in a pre designed proforma.

In all instances, the diagnosis was establish clinically as far as possible, except in case of ambiguity, in which case the diagnosis was confirmed with relevant investigations. Routine blood haemoglobin, complete blood counts, urine routine examination, blood sugar estimation were carried out whenever it was necessary. Skin scrapings, nail clipping for fungus, Tzanck smears and skin biopsies were done wherever indicated for confirmation of diagnosis.

\section{Data analysis}

Data were assessed using statistical program SPSS version 22.00. $P$ value $<0.05$ will be considered to be significant. 


\section{RESULTS}

Of the total of 500 participants in our study, 263 $(52.6 \%)$ were males and the rest were females (Table 1). 305 (61\%) participants belonged to the $60-70$ years age group while only $11.8 \%$ participants were over 80 years of age. The highest age of the participant in our study was 93 years.

There was no significant difference of gender distribution among the patients belonging to different age groups.

Table 1: Distribution of cases according to gender

\begin{tabular}{|c|c|c|c|}
\hline Gender & Number of patients & Percentage & Mean age \\
\hline Male & 263 & $52.60 \%$ & $70.07 \pm 7.61$ \\
\hline Female & 237 & $47.40 \%$ & $70.43 \pm 8.16$ \\
\hline Total & 500 & $100 \%$ & $\mathrm{P}=0.615$ \\
\hline
\end{tabular}

$[p$ value $=0.113]$

Table 2: Duration of lesions

\begin{tabular}{|c|c|c|c|c|c|}
\hline Duration of lesions (in years) & Male & Percentage & Female & Percentage & Total \\
\hline$<1$ month & 13 & 5.20 & 24 & 9.60 & 33 \\
\hline $1-6$ months & 43 & 17.20 & 43 & 17.20 & 86 \\
\hline $6-12$ months & 84 & 31.93 & 80 & 33.75 & 168 \\
\hline$>1$ year & 123 & 46.78 & 90 & 37.97 & 212 \\
\hline Total & 263 & $100 \%$ & 237 & $100 \%$ & 500 \\
\hline Mean \pm SD & & \multicolumn{2}{|c|}{$3.12 \pm 0.92$} \\
\hline
\end{tabular}

[Mean age $<1$ years $=69.54 \pm 7.31$ vs $>1$ years $=70.29 \pm 7.92 ; p=0.596$ ]

Majority of participants had long standing diseases, with 212 participants (46.78\%) complaining of the duration of disease being more than a year.

Table 3: Physiological changes in the skin and hair, with gender wise distribution

\begin{tabular}{|c|c|c|c|}
\hline Physiological change & Males (N=263) & Females (N=237) & Total (N=500) \\
\hline Senile purpura & $57(21.7 \%)$ & $37(15.6 \%)$ & $94(18.8 \%)$ \\
\hline Xerosis & $39(14.8 \%)$ & $42(17.7 \%)$ & $81(16.2 \%)$ \\
\hline Senile comedones & $39(14.8 \%)$ & $30(12.7 \%)$ & $69(13.8 \%)$ \\
\hline Senile lentigines & $17(6.5 \%)$ & $12(5.1 \%)$ & $29(5.8 \%)$ \\
\hline Greying of hair & $237(90.1 \%)$ & $214(90.3 \%)$ & $451(90.2 \%)$ \\
\hline
\end{tabular}

Senile purpura was the most common physiological change (18.8\%), followed by xerosis (16.2\%). Senile comedones and senile lentigines were seen in $13.8 \%$ and $5.8 \%$ patients respectively. 
Some degree of greying of hair was seen in $90.2 \%$ of participants which is a very common physiological change associated with ageing.

Table 4: Overall distribution pattern of various pathological dermatoses, with gender wise distribution*

\begin{tabular}{|l|c|c|c|}
\hline Type of dermatosis & $\begin{array}{c}\text { Males } \\
(\mathbf{N = 2 6 3 )}\end{array}$ & $\begin{array}{c}\text { Females } \\
(\mathbf{N = 2 3 7 )}\end{array}$ & $\begin{array}{c}\text { Total } \\
(\mathbf{N}=\mathbf{5 0 0 )}\end{array}$ \\
\hline Infections & $113(43 \%)$ & $82(34.6 \%)$ & $195(39 \%)$ \\
\hline Infestations & $15(5.7 \%)$ & $9(3.8 \%)$ & $24(4.8 \%)$ \\
\hline Pruritus & $142(54 \%)$ & $133(56.1 \%)$ & $275(55 \%)$ \\
\hline Eczematous diseases & $101(38.4 \%)$ & $73(30.8 \%)$ & $174(34.8 \%)$ \\
\hline Papulosquamous diseases & $10(3.8 \%)$ & $11(4.6 \%)$ & $21(4.2 \%)$ \\
\hline Pigmentary diseases & $16(6.1 \%)$ & $16(6.7 \%)$ & $32(6.4 \%)$ \\
\hline Benign tumors & $178(67.7 \%)$ & $144(60.7 \%)$ & $322(64.4 \%)$ \\
\hline Immunobullous disorders & $4(1.5 \%)$ & $4(1.7 \%)$ & $8(1.6 \%)$ \\
\hline Metabolic disorders & $7(2.7 \%)$ & $4(1.7 \%)$ & $11(2.2 \%)$ \\
\hline $\begin{array}{l}\text { Connective tissue diseases and } \\
\text { disorders of connective tissue }\end{array}$ & $30(11.4 \%)$ & $34(14.3 \%)$ & $64(12.8 \%)$ \\
\hline Malignant and pre-malignant diseases & $5(1.9 \%)$ & $3(1.3 \%)$ & $8(1.6 \%)$ \\
\hline Drug reactions & $6(2.3 \%)$ & $6(2.5 \%)$ & $12(2.4 \%)$ \\
\hline
\end{tabular}

* Several patients presented with more than one entity, hence, the arithmetic total is not representative of the actual number of patients presenting with the disease group.

Most common dermatosis noted in the target population was benign tumors, present in 322 patients (64.4\%). Second most common disease group affecting the elderly was the infections and infestations group, being present in 215 patients (43\%). Infections were present in 195 patients (39\%) while infestations were present in 24 patients (4.8\%). Four patients presented with infection along with infestation.

This was followed by eczematous diseases which were present in 174 patients (34.8\%). Papulosquamous disorders were present in $4.2 \%$ patients, while immunobullous disorders as well as malignant/pre-malignant conditions were present in $1.6 \%$ of the patients (8 cases each).

\section{DISCUSSION}

The population over age 60 years has increased so are the number of patients seeking geriatric care. Most common skin changes are physiological, but they may adversely affect an older person's health and quality of life. In this study, we attempted to determine the frequency as well as the age and gender distributions of common cutaneous changes in elderly people. Additionally, an attempt was made to look for an association between age related skin changes and sun exposure. The region of northern India, especially western Rajasthan, has a mixed type of population - that is, Hindus and Muslims with various others. Also, the climate of the region and life style of general population are such that a number of skin changes are encountered in the elderly individuals.

Males outnumbered females with male to female ratio 1.11:1. This is largely in tune with other studies ${ }^{10-13}$. In a few studies females have outnumbered male patients ${ }^{14-15}$.

Majority of our patients (42.4\%) had the disease for more than one year before they sought medical consultation. This delay can be attributed to two reasons- 1 ) Most dermatoses in elderly people either do not cause significant morbidity and mortality or 2) Because of 
dependency on others elderly people do not find it easy to visit hospital. There is a very thin line in deciding what is physiological and what is pathological in older person's skin. Many changes and lesions are normal, except occasionally in degree and number. In this study we considered senile purpura, xerosis, senile comedone and senile lentigens as physiological. While idiopathic guttate hypomelanosis was placed in the pigmentary disorders sub-group among the pathological changes.

\section{CONCLUSSION}

Males outnumbered females with male to female ratio 1.11:1. The distribution and frequency of various dermatoses varies significantly from country to country and region to region. This study will help to identify the patterns of geriatric skin disorders in the target population for optimization of delivery of health care services.

\section{REFERENCES}

1. WHO Aging: Exploding the myths. J Indian Med Association 1999;97(4):138-40.

2. Chaudhury, RH. Ageing in Nepal. Asia-Pacific Popul J 2004;19(1): 61-77

3. Pai M. The Elderly part! Old age home- Om ashram 2002. Banglore Omashram trust. 2002[ cited 2019 March 21]

4. Suryakantha $\mathrm{AH}$. Community Medicine with Recent Advances 3rd edition 2013. Published by Jaypee Brothers Medical Publishers ( P) Ltd. N.D. India .

5. Defusing the demographic time-bomb in Germany. Bulletin World Health Organization. 2012;90:6-7.

6. Dawale AK, Mudey A, Lanjewar A, Wagh VV. Study of morbidity pattern in inmates of old age homes in urban areas of central India. Indian Academy of Geriatrics Journal 2010; 6(1): 23-27.

7. Ingle GK, Nath A. Geriatric health in India: concerns and solutions. Indian journal of Community Medicine 2008; 33(4): 21

8. Prakash R, Chaudhary SK, Singh US. A study of morbidity pattern among geriatric population in an urban area of Udaipur. Indian J Commun Med 2004;29(1):35-40.

9. Sarkar S. Morbidity profile of aged population of old age home in Calcutta. Ind J Pub Health 2003;47(2): 47-50

10. Kshetrimayum $S$, Thokchom NS, Vanlalhriatpuii NA, Hafi B. Pattern of geriatric dermatoses at a tertiary care center in North-East India. Int J Res Dermatol. 2017 Dec;3(4):527-534

11. Raveendra L. A clinical study of geriatric dermatoses. Our Dermatol Online. 2014;5:235-9.

12. Nair P, Bodiwala N, Arora T, Patel S, Vora R. A study of geriatric dermatosis at a rural hospital in Gujarat. J Indian Acad Geriatr. 2013;9(1):15-9.

13. Pavithra $S$, Shukla $P$, Pai GS. Cutaneous manifestations in senile skin in coastal Goa. Nepal J Dermatol Venereol Leprol. 2010;9 (1):1-6.

14. Thapa DP, Jha AK, Kharel C, Shrestha S. Dermatological problems in geriatric patients: a hospital based study. Nepal Med Coll J. 2012;14:193-5.

15. Goyal A, Balai M, Mittal A, Khare AK, Gupta LK. Pattern of geriatric dermatoses at a Tertiary Care Teaching Hospital of South Rajasthan, India. Int J Dermatol. 2006;45: 672-6. 